\title{
A Case Study on the Implementation of Quality Control Circle in the Production Line of a Manufacturing Company
}

\author{
Norhamizah Satar and Baba Md Deros \\ Department of Mechanical and Materials Engineering \\ Faculty of Engineering \& Built Environment, \\ University Kebangsaan Malaysia \\ 43600 UKM Bangi, Selangor, \\ Malaysia \\ Email:hjbaba@eng.ukm.my \\ Received Date: $28^{\text {th }}$ August 2006 Accepted Date: $7^{\text {th }}$ March 2007
}

\begin{abstract}
This paper is based on a case study of Quality Control Circle (QCC) implementation in the production line of a manufacturing company in Malaysia. In this paper, the authors would like to share their experience of a success story in implementing the QCC, which is known as Small Group Activity (SGA) in their production line. The SGA was implemented with total involvement of its employees and fully supported by committed top management. As an example, the authors discuss their experiences in detail the SGA activities implemented in the production-engineering department. The case study presented showed and proved that by empowering the lower level employees through implementing QCC activity, the company had gained a substantial human development and cost savings. Finally, the authors also like to share the problems that they had encountered during the implementation of the SGA activities and how they had remedied these difficulties.
\end{abstract}

Keywords: QCC, SGA, employee, empowering, cost.

\section{ABSTRAK}

Kertas kerja ini ditulis berdasarkan kepada sebuah kajian kes pelaksanaan Kumpulan Kawalan Kualiti (KKK) di bahagian pengeluaran di sebuah syarikat pembuatan di Malaysia. Penulis kertas kerja ingin berkongsi pengalaman mereka mengenai kejayaan yang telah mereka capai ketika melaksanakan KKK di bahagian pengeluaran. Di syarikat ini, KKK dikenali dengan nama Aktiviti Kumpulan Kecil (AKK). AKK telah dilaksanakan dengan penglibatan keseluruhan kakitangan dan mendapat sokongan padu daripada pihak pengurusan atasan. Sebagai contoh, penulis akan membincangkan pengalaman mereka secara terperinci mengenai aktiviti AKK yang telah dilaksanakan di Jabatan Kejuruteraan Pengeluaran. Kajian kes yang dibentangkan dapat menunjukkan dan membuktikan bahawa dengan menurunkan sedikit kuasa kepada kakitangan bawahan menerusi pelaksanaan aktiviti KKK, syarikat itu telah mendapat pulangan dari aspek pembangunan sumber manusia dan penjimatan kos. Di akhir kertas kerja ini, penulis juga ingin berkongsi dengan pembaca mengenai masalah yang telah mereka tempohi ketika melaksanakan aktiviti AKK dan bagaimana mereka mengatasi kesukaran itu.

Kata kunci: KKK, AKK, kakitangan, penurunan kuasa, kos. 


\section{INTRODUCTION}

After the Second World War, Japan's industrial units were worst hit and became paralyzed.Thus, there is a need for Japan to recover its economy and industry very fast. Apart from that Japan required help to wipe out their poor quality image. Hence, Dr. Deming from USA was invited to teach the Japanese top managers, engineers and industrial workers on the quality concepts and management (Summers 2005; Deming 1986). Even though Quality Circle (QC) was first introduced to a Western nation but it was rejected because of the Taylorism concept. Dr. Deming accepted the invitation from Japan and began teaching the quality concept and management to Japanese top managers, engineers and industrial workers (Dale 1994; Deming 1986). Since then, Japan was very successful with this new approach and became the industrial giant at the east. In early 1980s, the Prime Minister of Malaysia Tun Dr. Mahathir Mohamed launched the Look East Policy and Malaysia welcomed Japanese investors to set up their multinational companies in Malaysia. As a result of this new Look East Policy, many multi-national companies setup their factories in Malaysia. In short, by getting the technological knowledge from West and working under Japanese work ethics thus enables Malaysian workers to easily adapt these modern quality management concepts.

In September 21, 2002, 97 QCs competed in the Malaysian National QCC Convention 2002 (MNQC 2002). These QCCs were competing in three different categories: 31 QCCs for the Electronic and Electrical (E\&E) Sector, 34 QCCs for the other Manufacturing Sectors and the remaining 32 in the Service Sector. For example, the contribution from 31 QCCs in the E\&E sector is $61 \%$ of the total RM67 million savings achieved by all the 97 participating QCCs in this National QCC Convention in 2002. This represents a total saving of RM41 million from these 31 QCC projects. It shows that quality circles activities had achieved a significant impact in term of monetary saving. One of the QCC team by the named "Sekapur Sirih" had participated in this convention. They won 3 Star Gold Medal and amongst the TOP 10 group. Later in this paper, the authors shall use one of the projects as the case study subject.

\section{WHAT IS A QUALITY CONTROL CIRCLE?}

A Quality Control Circle (QCC) is a small group of between three and twelve people that are empowered to improve work processes and process capability (Foster 2001). Normally, the QCC teams members comes from the same or similar work areas, voluntarily meeting together regularly for about an hour per week in paid time, usually under the leadership of their own supervisor, and trained to identify, analyze, and solve some of the problems in their work, presenting solutions to management, and where possible, implementing the solutions themselves (Madura 2004; Talib et al. 2003). In other words, the QCC teams conduct-brainstorming sessions to find out the quality improvement methods and identify causes of quality problems by using the quality improvement tools (Deros, 2004; Evans \& Dean 2003).

According to JUSE (1994) the basic concepts behind QCC are as follows:

(i) To contribute to the improvement and development of the enterprise;

(ii) To respect humidity and to build meaningful life and cheerful workplace;

(iii) Display human capability and to draw out each individual's infinite potential.

\section{QUALITY CONTROL CIRCLE IN THE PRODUCTION LINE OF A MANUFACTURING COMPANY}

This company is a subsidiary of a multinational company. It was established in the year 1981, producing television and monitor components for the worldwide market (Hitachi 1985). Its parent company in Japan was recognized of its excellence in the theory and application of statistical quality control and was awarded "The Deming Prize" in 1955 (Aquayo 2000). In this company, the Quality Circle is known as a Small Group Activity or in short SGA.

The SGA was initially started in 1983 with $100 \%$ involvement with more than 200 groups (Hitachi 1985). Unfortunately due to inexperience, poor education and training, lack of commitment and no incentives, the effort was a total failure. Later in 1991, the second attempt in implementing the SGA was made. The new approached was adopted by the top management with a proper organized planning, engaged a consultant to give training and education, and set-up a group 
in a stages (Hitachi 1992). Some investment was put-in for education, facilities, and manpower plus with attractive incentives. The program also includes a morale boosting activities such as an outing, a sport carnival and a workshop session.

\section{METHODOLOGY}

In this study, the case study methodology was employed throughout the implementation of the quality control circle by using the small group activities (SGA). The quality improvement tools used to perform this case study were the 7 Basic QC tools and 7 Advance QC tools as listed below:

$\begin{array}{ll}\text { - } & \text { PDCA, } \\ \text { - } & \text { Cause and Effect Diagram } \\ \text { - } & \text { Pareto Chart, } \\ \text { - } & \text { Gantt Chart, } \\ \text { - } & \text { Run Chart } \\ \text { - } & \text { Interrelation Diagram } \\ \text { - } & \text { T- Diagram, } \\ \text { - } & \text { Tree Diagram } \\ \text { - } & \text { Check Sheet } \\ \text { - } & \text { Brainstorming }\end{array}$

The group was comprised of 8 members from the various job scopes. The members were selected from the Production Engineering staffs ranking from Clerk, Technician, Supervisor and Assistant Officer. A Manager and a Facilitator guided the team. At the beginning stage, they formed their project team, select their team leader and drafted their milestone chart in the form of PDCA (Plan, Do, Check, Action) as shown in Table 1. They selected a jig improvement as their project theme and the project duration was 6 months.

The group conducted the brainstorming session and selected the project by voting. They agreed to reduce rejection ratio of diode mounting process due to diode lead hanging. Based on the criteria as given below:

- $\quad$ Easy to collect data

- Members ability and specialty

- Achievable in 6 months

- Cost saving

- Related to company objective

The QCC team for this particular project conducted their project meeting on weekly basis. On average, more than $90 \%$ of the team members attended their weekly project progress meeting.

\section{PROJECT DEFINITION}

The project was conducted at the transformer production line. The process was located at the diode-mounting machine. The process is to solder the seven pieces of diodes to the high voltage terminal pin. The good solder process will result in a good adhesion of diodes to pin. Whereas, if the diode-lead hanging, drop or missing it will be considered as a reject part. From the data collected, the diode lead hanging contributed about $40 \%$ of total problem as shown in Table 2.

\section{PROBLEM ANALYSIS}

After completing identifying the problem, the group performed the analysis of each problem. The brainstorming session was held to list-out the possible causes of the problems. The causes were due to Man, Machine, Method and Material (4M) that need to be identified. There were 15 causes as shown in Figure 1.

\section{CAUSE AND ANALYSIS}

After identifying and performing the cause and effect analysis, the group found 8 causes were true and plotted them in the interrelation diagram to show their relationship amongst causes as shown in the Figure 2.

They found 3 major causes that need further and detail analysis. These 3 major causes were arranged in tree diagram as shown in Figure 3. Having done that, the group found that there were only 3 major causes that need for further investigation and detail analysis. These 3 major causes were arranged in the tree diagram a shown in Figure 3.

For diode in the roll bend, the investigation was carried out to check the diode condition in the roll at the starting point and at the ending point. The diode lead was bent at these two positions. The cutter condition was in good condition and it was not the cause of the vibration, whereas the stopper height was not correct and need adjustment. This was confirmed by checking with the feeler gauge, which showed that the upper cutter and the lower cutter were not properly aligned. For the diode lead lifted due to the 
TABLE 1. Milestone chart

\begin{tabular}{|l|l|l|l|l|l|l|l|l|l|l|}
\hline Activity Month & 1 & 2 & 3 & 4 & 5 & 6 & 7 & 8 & 9 & 10 \\
\hline Theme & & & & & & & & & & \\
\hline Project Selection & & & & & & & & & & \\
\hline Data & & & & & & & & & & \\
\hline Cause & & & & & & & & & & \\
\hline Evaluation & & & & & & & & & & \\
\hline Implement & & & & & & & & & & \\
\hline Monitor & & & & & & & & & & \\
\hline Standardization & & & & & & & & & & \\
\hline Convention & & & & & & & & & & \\
\hline
\end{tabular}

TABLE 2. Diode rejection data

\begin{tabular}{|c|c|c|c|c|c|c|}
\hline $\begin{array}{l}\text { Month } \\
\text { Rejection }\end{array}$ & 1 & 2 & 3 & 4 & Total & Avg/Mth \\
\hline $\begin{array}{l}\text { Diode Lead } \\
\text { Drop }\end{array}$ & 651 & 768 & 329 & 1,206 & 2,954 & 738.5 \\
\hline $\begin{array}{l}\text { Diode Lead } \\
\text { Hanging }\end{array}$ & 432 & 698 & 716 & 1,563 & 3,409 & 852.3 \\
\hline $\begin{array}{l}\text { Diode Lead } \\
\text { Missing }\end{array}$ & 0 & 634 & 940 & 496 & 2,070 & 517.5 \\
\hline
\end{tabular}

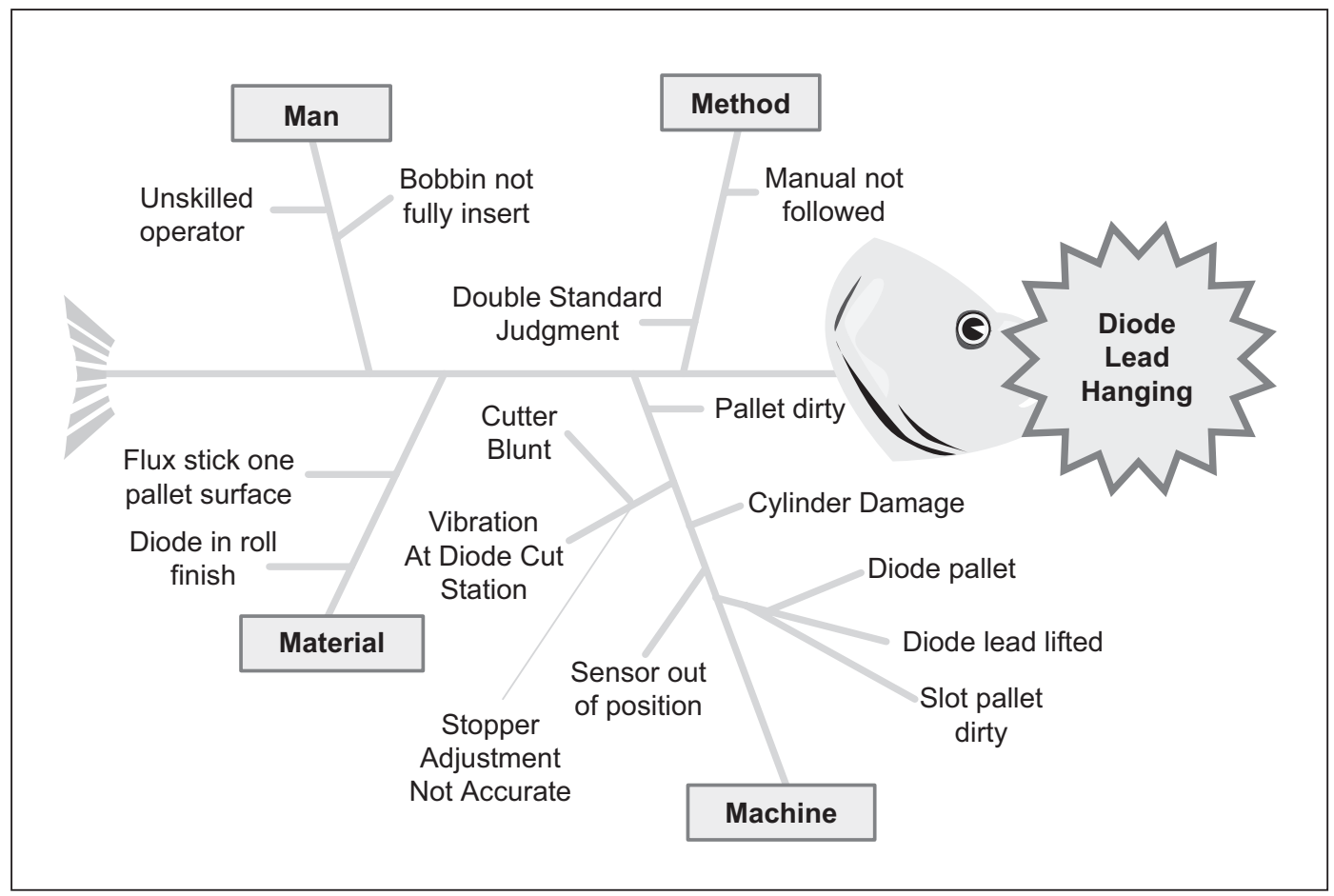

FIGURE 1. Cause and effect diagram 


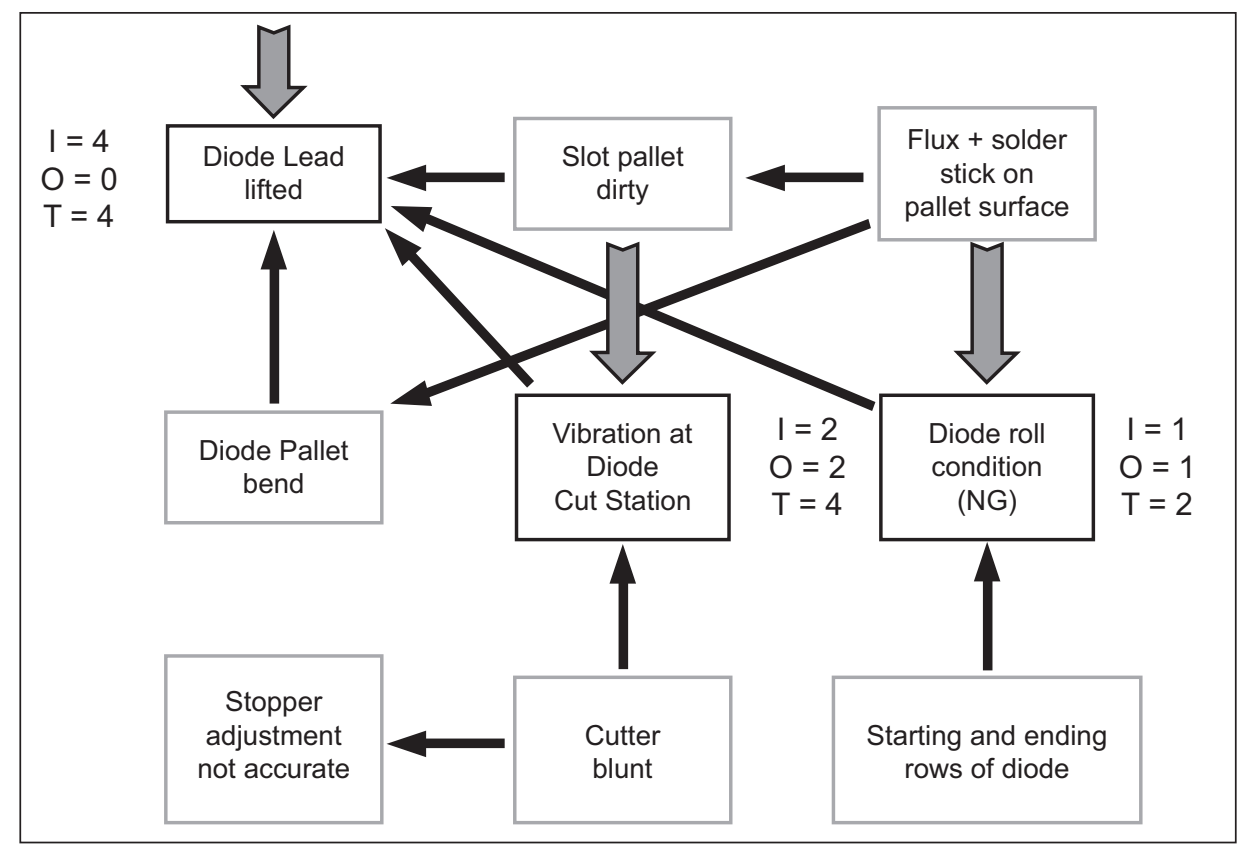

FIGURE 2. Interrelation diagram

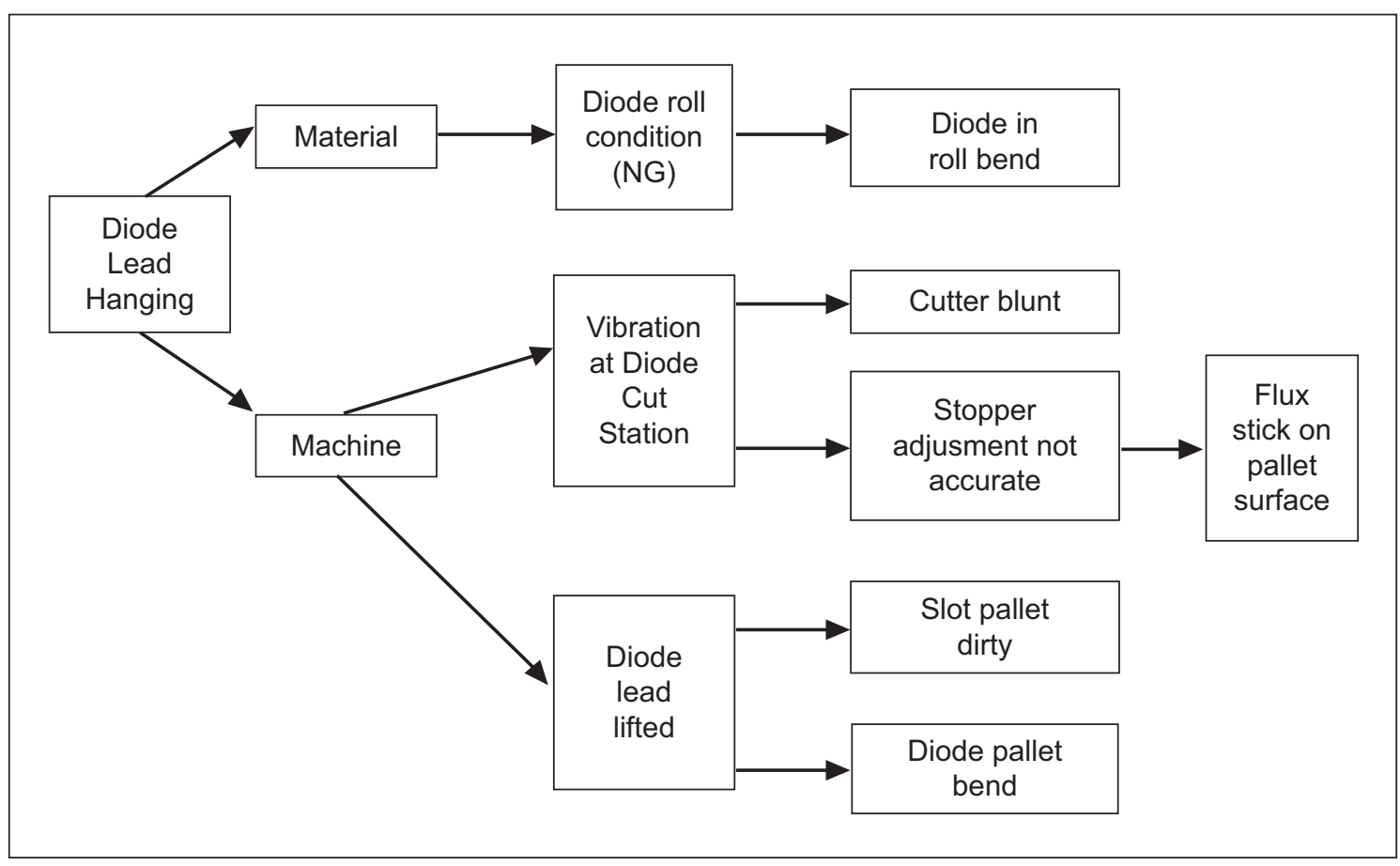

FIGURE 3. Tree diagrams of causes

slot pallet dirty, it was found true after careful observation done on the process. They decided not to tackle the diode bend in roll because it was beyond their job scope.

The improvement to eliminate the vibration at diode cutting station by putting a silicone rubber at the stopper area was adopted. The stopper also needs to be adjusted at the correct level. The solution idea was given 4 points as shown in Table 3.
For the pallet dirty problem, the idea of cleaning the pallet manually by operator was found practical and effective. The operator needs to do an extra job. Table 4 shows the result from the brainstorming session.

\section{IMPLEMENT SOLUTION}

All ideas were carried-out by the team. The ideas to place a silicone rubber and adjust the stopper were handled by the technical staff. Figure 4 
TABLE 3. Alternative solutions for vibration problem

\begin{tabular}{|c|c|c|c|c|c|c|c|c|}
\hline \multicolumn{9}{|c|}{ Advantage \& Disadvantage of Alternative Solution } \\
\hline \multirow{2}{*}{ No. } & \multirow{2}{*}{ Key Idea } & \multirow{2}{*}{ Advantage } & \multirow{2}{*}{ Disadvantage } & \multicolumn{4}{|c|}{ Criteria } & \multirow{2}{*}{ Total } \\
\hline & & & & 1 & 2 & 3 & 4 & \\
\hline 1 & $\begin{array}{l}\text { Put silicon } \\
\text { pad } \\
\text { at cylinder }\end{array}$ & $\begin{array}{l}\text { Absorb impact } \\
\text { from being transmitted } \\
\text { to solder station }\end{array}$ & Nil & 1 & 1 & 1 & 1 & 4 \\
\hline 2 & $\begin{array}{l}\text { Adjust the } \\
\text { stopper }\end{array}$ & $\begin{array}{l}\text { 1> Imp. m/c tact time } \\
2>\text { Reduce vibration } \\
\text { 3> Reduce cutter wear }\end{array}$ & Nil & 1 & 1 & 1 & 1 & 4 \\
\hline
\end{tabular}

TABLE 4. Alternative solutions for pallet dirty

\begin{tabular}{|c|c|c|c|c|c|c|c|c|}
\hline \multicolumn{9}{|c|}{ Advantage \& Disadvantage of Alternative Solution } \\
\hline \multirow{2}{*}{ No. } & \multirow{2}{*}{ Key Idea } & \multirow{2}{*}{ Advantage } & \multirow{2}{*}{ Disadvantage } & \multicolumn{4}{|c|}{ Criteria } & \multirow{2}{*}{ Total } \\
\hline & & & & 1 & 2 & 3 & 4 & \\
\hline 1 & $\begin{array}{l}\text { Clean the } \\
\text { pallet }\end{array}$ & $\begin{array}{l}\text { To ensure the pallet } \\
\text { is clean }\end{array}$ & $\begin{array}{l}\text { Add job to } \\
\text { operator }\end{array}$ & 1 & 1 & 1 & 1 & 4 \\
\hline
\end{tabular}

Put rubber in between stopper and cylinder body

BEFORE

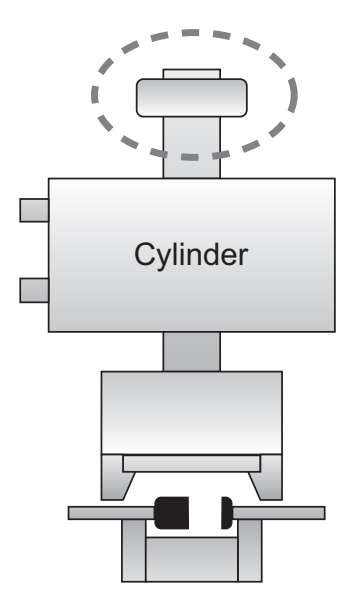

AFTER

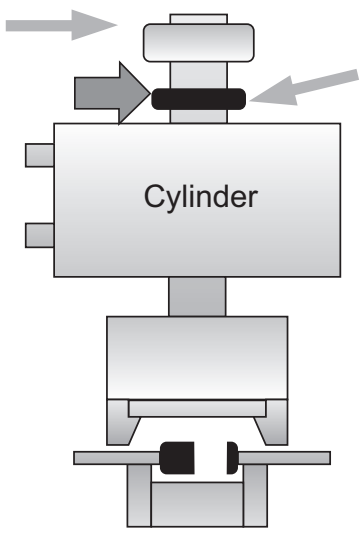

\begin{tabular}{|c|c|c|c|c|c|}
\hline $\begin{array}{c}\text { Purpose } \\
\text { "What" }\end{array}$ & $\begin{array}{c}\text { Factor } \\
\text { "Where" }\end{array}$ & $\begin{array}{c}\text { Cause } \\
\text { "Why" }\end{array}$ & $\begin{array}{c}\text { C/Measure } \\
\text { "How" }\end{array}$ & $\begin{array}{c}\text { Resp. } \\
\text { "Who" }\end{array}$ & $\begin{array}{c}\text { Period } \\
\text { "When" }\end{array}$ \\
\hline $\begin{array}{c}\text { Prevent } \\
\text { vibration at } \\
\text { diode Cut } \\
\text { Station }\end{array}$ & $\begin{array}{c}\text { Cutting } \\
\text { Station }\end{array}$ & $\begin{array}{c}\text { To absorb } \\
\text { vibration } \\
\text { impact }\end{array}$ & $\begin{array}{c}\text { Put rubber } \\
\text { bet. } \\
\text { cylinder } \\
\text { and stopper }\end{array}$ & Rosli & $\begin{array}{c}\text { ASAP: } 2 \text { hrs } \\
-21 / 6 / 99\end{array}$ \\
\hline
\end{tabular}

FIGURE 4. Ideas illustration 
TABLE 5. Check sheet on observation

\begin{tabular}{|c|c|c|c|}
\hline No. & Possible Cause & Analysis & Solution \\
\hline 1 & Rubber torn & $\begin{array}{l}\text { 1st week after implementation, } \\
\text { we observe during operation } \\
\text { time. And we found no more } \\
\text { wave on solder surface but in } 2 \text { nd } \\
\text { week onwards we found wave on } \\
\text { solder surface happened again. }\end{array}$ & $\begin{array}{l}\text { Change rubber from Silicon } \\
\text { to more elastic rubber. Our } \\
\text { proposal is to replace to Anti } \\
\text { Static Rubber. }\end{array}$ \\
\hline
\end{tabular}

Data Check sheet on observation after 1 st countermeasure ( 2 weeks)

\begin{tabular}{|c|c|c|c|c|c|c|c|c|c|c|c|c|c|c|}
\hline \multirow[b]{2}{*}{ Condition } & \multicolumn{6}{|c|}{ June } & \multicolumn{8}{|c|}{ July } \\
\hline & 22 & 23 & 24 & 25 & 29 & 30 & 1 & 2 & 5 & 6 & 7 & 8 & 9 & 12 \\
\hline $\begin{array}{l}\text { Wave on Solder } \\
\text { surface }\end{array}$ & $x$ & $x$ & $x$ & $x$ & $x$ & $x$ & $x$ & $x$ & $x$ & $\checkmark$ & $\checkmark$ & $\checkmark$ & $\checkmark$ & $\checkmark$ \\
\hline
\end{tabular}

TABLE 6. Check sheet on observation

Data Check sheet on observation after change Anti Static Rubber (2 weeks )

\begin{tabular}{|c|c|c|c|c|c|c|c|c|c|c|c|c|c|c|c|c|c|}
\hline \multirow{2}{*}{ Condition } & \multicolumn{14}{|c|}{ July } & \multicolumn{3}{|c|}{ August } \\
\hline & 13 & 14 & 15 & 16 & 19 & 20 & 21 & 22 & 23 & 26 & 27 & 28 & 29 & 30 & 2 & 3 & 4 \\
\hline $\begin{array}{l}\text { Wave on Solder } \\
\text { surface }\end{array}$ & $x$ & $x$ & $x$ & $x$ & $x$ & $x$ & $x$ & $x$ & $x$ & $x$ & $x$ & $x$ & $x$ & $x$ & $x$ & $x$ & $x$ \\
\hline
\end{tabular}

$\mathrm{x}$ :Wave not exist
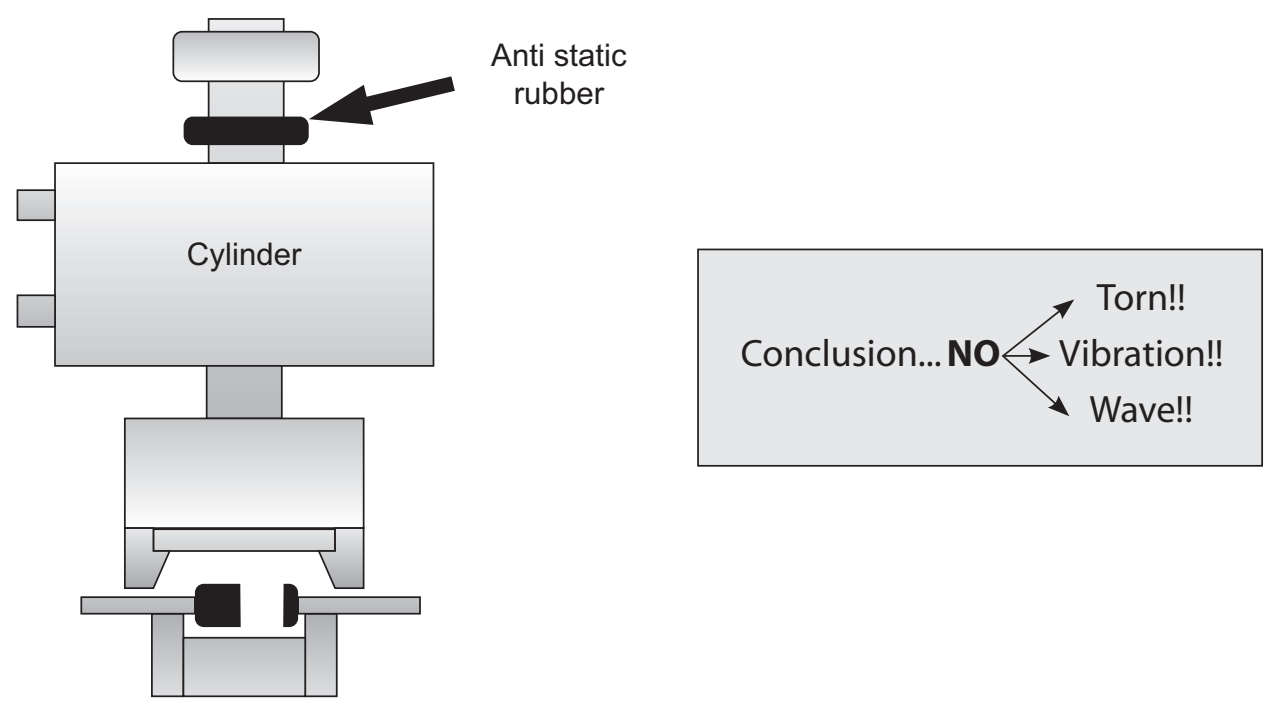
TABLE 7. Check sheet on pallet cleaning

Monitoring Result:- on Cleaning Pallet Manually

Data Check sheet on pallet clean manually ( July 99')

\begin{tabular}{cccccccccccccccc}
\hline \multicolumn{1}{c}{ MORNING SHIFT } & \multicolumn{1}{c}{ AFTERNOON SHIFT } & \multicolumn{7}{c}{ NIGHT SHIFT } \\
\hline Date & 6.55 & 9.00 & 12.00 & $\begin{array}{c}\text { CHK } \\
\text { BY }\end{array}$ & Date & 3.30 & 5.00 & 7.00 & $\begin{array}{c}\text { CHK } \\
\text { BY }\end{array}$ & Date & 11.00 & 1.00 & 3.00 & $\begin{array}{c}\text { CHK } \\
\text { BY }\end{array}$ \\
\hline $1 / 7$ & $\checkmark$ & $\checkmark$ & $\checkmark$ & Leha & $1 / 7$ & $\checkmark$ & $\checkmark$ & $\checkmark$ & Husna & $1 / 7$ & $\checkmark$ & $\checkmark$ & $\checkmark$ & Imah \\
$2 / 7$ & $\checkmark$ & $\checkmark$ & $\checkmark$ & Leha & $2 / 7$ & $\checkmark$ & $\checkmark$ & $\checkmark$ & Husna & $2 / 7$ & $\checkmark$ & $\checkmark$ & $\checkmark$ & Imah \\
$5 / 7$ & $\checkmark$ & $\checkmark$ & $\checkmark$ & Leha & $5 / 7$ & $\checkmark$ & $\checkmark$ & $\checkmark$ & Husna & $5 / 7$ & $\checkmark$ & $\checkmark$ & $\checkmark$ & Imah \\
$6 / 7$ & $\checkmark$ & $\checkmark$ & $\checkmark$ & Leha & $6 / 7$ & $\checkmark$ & $\checkmark$ & $\checkmark$ & Husna & $6 / 7$ & $\checkmark$ & $\checkmark$ & $\checkmark$ & Imah \\
$7 / 7$ & $\checkmark$ & $\checkmark$ & $\checkmark$ & Leha & $7 / 7$ & $\checkmark$ & $\checkmark$ & $\checkmark$ & Husna & $7 / 7$ & $\checkmark$ & $\checkmark$ & $\checkmark$ & Imah \\
$8 / 7$ & $\checkmark$ & $\checkmark$ & $\checkmark$ & Leha & $8 / 7$ & $\checkmark$ & $\checkmark$ & $\checkmark$ & Husna & $8 / 7$ & $\checkmark$ & $\checkmark$ & $\checkmark$ & Imah \\
$9 / 7$ & $\checkmark$ & $\checkmark$ & $\checkmark$ & Leha & $9 / 7$ & $\checkmark$ & $\checkmark$ & $\checkmark$ & Husna & $9 / 7$ & $\checkmark$ & $\checkmark$ & $\checkmark$ & Imah \\
$12 / 7$ & $\checkmark$ & $\checkmark$ & $\checkmark$ & Leha & $12 / 7$ & $\checkmark$ & $\checkmark$ & $\checkmark$ & Husna & $12 / 7$ & $\checkmark$ & $\checkmark$ & $\checkmark$ & Imah \\
$13 / 7$ & $\checkmark$ & $\checkmark$ & $\checkmark$ & Leha & $13 / 7$ & $\checkmark$ & $\checkmark$ & $\checkmark$ & Husna & $13 / 7$ & $\checkmark$ & $\checkmark$ & $\checkmark$ & Imah \\
$14 / 7$ & $\checkmark$ & $\checkmark$ & $\checkmark$ & Leha & $14 / 7$ & $\checkmark$ & $\checkmark$ & $\checkmark$ & Husna & $14 / 7$ & $\checkmark$ & $\checkmark$ & $\checkmark$ & Imah \\
$15 / 7$ & $\checkmark$ & $\checkmark$ & $\checkmark$ & Leha & $15 / 7$ & $\checkmark$ & $\checkmark$ & $\checkmark$ & Husna & $15 / 7$ & $\checkmark$ & $\checkmark$ & $\checkmark$ & Imah \\
$16 / 7$ & & & & Leha & $16 / 7$ & & & & Husna & $16 / 7$ & & & & Imah \\
\hline
\end{tabular}

BEFORE

Dec $98 \sim$ Mac 99
AFTER

Jun $99 \sim$ Aug 99

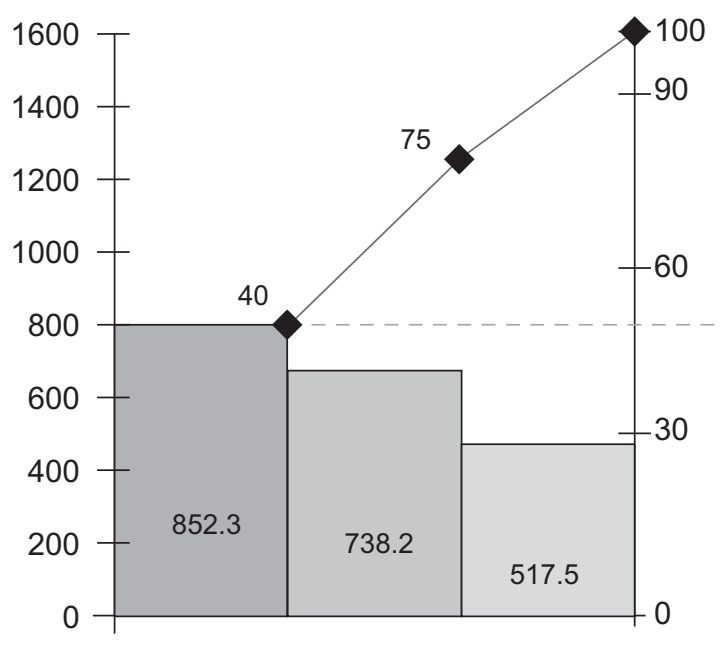

Rejection Items
Qty average/month Rejection ratio (\%)

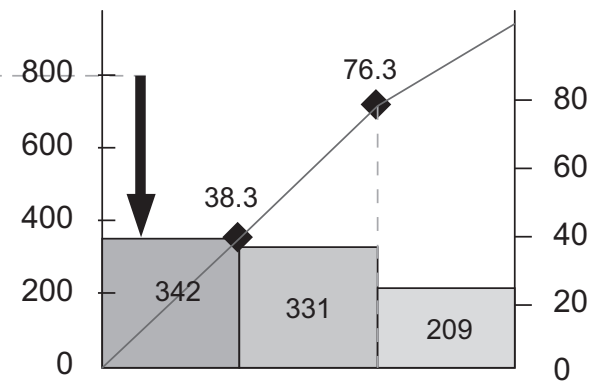

Rejection Items

FIGURE 5. Pareto before and after

shows the ideas illustration.Cleaning the pallet was assigned to operator to do with the check sheet to record the job done.

\section{MONITORING RESULT}

The implemented countermeasure was monitored. The silicone pad was found torn after 10 days in operation. Table 5 shows the check sheet on observation.

Later, the silicone pad was change to antistatic rubber. The monitoring continued. It was found the antistatic rubber could last longer. There was no more vibration. (Table 6 shows the check sheet on observation).

The pallet cleaning by operator was done 3 times per shift. The check sheet was filled-up and inspection done shown the pallet was free from the solder debris and flux residues. Table 7 shows the check sheet data on pallet cleaning.

The overall monitoring result of diode lead hanging rejection was taken after all the corrective activities done. The total rejection was reduced 
To: Section Concern

From:PE Dept

Date: $20^{\text {th }}$ Sep 1999

\section{Re: Improvement Item Implemented At $2^{\text {nd }}$ Diode Mounter}

Please be informed that PE Dept has performed the quality improvement project "To Reduce Diode Rejection For Mig98 At $2^{\text {nd }}$ Diode Mounter"

\section{Purpose}

1. To reduce rejection ratio by $50 \%$

2. To improve machine operation ratio

By Implementing

1. Place anti static rubber $(\mathrm{t}=2 \mathrm{~mm})$ between stopper and cylinder

2. Adjust stopper ( $8 \sim 10 \mathrm{~mm}$ height) and put marking

3. Clean pallet manually before starting work ( $3 \mathrm{x} / \mathrm{shift})$

FIGURE 6. Standardization notice

from $852 \mathrm{pcs} / \mathrm{mth}$ to $342 \mathrm{pcs} / \mathrm{mth}$, which indicates the achievement of $59.9 \%$. The Pareto chart was plotted before and after the countermeasure. Figure 5 shows the overall result.

\section{STANDARDIZATION}

The standardization notice was prepared and informed to all section concerned on the improvement done in order to get cooperation in sustaining the effectiveness. The production side shall follow the procedure of cleaning the pallet 3 times per shift. The antistatic rubber shall be checked from time-to-time on the condition and advised to include in the Preventive Maintenance checklist item. The marker line was drawn to indicate the correct level of the stopper adjustment. The notice sample is as shown in Figure 6.

\section{TANGIBLE AND INTANGIBLE BENEFIT}

The total saving from the project was RM17, 256 as shown in Table 6. Beside the monetary benefit the members of the group had improved their knowledge in 7 basic QC tools and some new advance QC tools. Their commitment towards the project was high which indicated by their

TABLE 8. Tangible benefits

\begin{tabular}{|c|c|c|c|c|}
\hline COST & \multicolumn{2}{|c|}{ Amt } & \multicolumn{2}{|c|}{ Remark } \\
\hline $\begin{array}{l}\text { Put antistatic rubber } 5 \mathrm{~mm} \text { at in between } \\
\text { stopper and cylinder body }\end{array}$ & \multicolumn{2}{|c|}{ F.O.C } & \multicolumn{2}{|c|}{ Recycle part } \\
\hline Adjust stopper and put marking & \multicolumn{2}{|c|}{ Nil } & \multicolumn{2}{|c|}{ Done by PE staff } \\
\hline Clean pallet manually & \multicolumn{2}{|c|}{ Nil } & \multicolumn{2}{|c|}{ During break time } \\
\hline BENEFIT & Before & After & Save & Unit \\
\hline Rejection quantity & 852 & 342 & 510.00 & pcs \\
\hline $\begin{array}{l}\text { Saving ( } 510 \times 7 \mathrm{pcs} / \text { bobbin } \times \mathrm{RM} 0.30 / \\
\text { diode) }\end{array}$ & & & $1,071.00$ & $\mathrm{RM} / \mathrm{mth}$ \\
\hline $\begin{array}{l}\text { Repair time }(510 p c \times 1.5 \mathrm{~min} / \text { coil } x \\
\text { RM0.48/pc) }\end{array}$ & & & 367.00 & $\mathrm{RM} / \mathrm{mth}$ \\
\hline Total per month saving & & & $1,438.00$ & $\mathrm{RM} / \mathrm{mth}$ \\
\hline Total per year saving & & & $17,256.00$ & RM/year \\
\hline
\end{tabular}


willingness to stay back to finish the project. The relationships among team members were strong and they helped each other. The leadership was shown in members by delegating and follow-ups the project progress. They managed to finish the project according to the schedule.

\section{PROBLEM FACED AND CONCLUSIONS}

There were few problems encountered during the project proceeding. Mainly was the daily workload responsibility on each worker. Sometimes, the project is delayed due to the tight schedule in the production floor. The worker needs to sacrifices by staying back to implement the projects. The manager and the facilitator helped and guided them whenever they had problems. The management provides incentives and sends them for an outing where they can get together and built-up trust and teamwork. Underlying the QC circle concept is the assumption that the causes of quality or productivity problems are unknown to workers and to managements. It is also assumed that shop-floor workers have hands-on knowledge, are creative, and can be trained to use this natural creativity in job problem solving. Quality circles, however, are a people-building, rather than people-using, approach. They aim at making

\section{REFERENCES}

Aguayo, R. 2000. Dr. Deming: The American Who Taught the Japanese About Quality. Published by arrangement with the Carol Publishing.

Benchmarks: Quality Circles 2002. http://domainoapp.npc.org.my/publications. nsf, 10th April 2002.

Crocker, O. L., Chiu, J. S. L. \& Charney, C. 1984. Quality Circles, A guide to participation and productivity. Copyright by Methuen Publications.

Dale, B. G. (ed.) .1994. Managing Quality, Prentice Hall, London.

Deming,W.E.1986.Quality, Productivity and Competitive Position, MIT Press.

Deros, B. M. 2004. Unpublished PhD Thesis, Faculty of Mechanical Engineering, Universiti Teknologi Malaysia, Skudai, Johor, Malaysia.

Evans,J.R.\&Dean,J.W.2003.Total Quality:Management, Organization and Strategy, 3rd Edition,Thomson, every worker a decision maker concerning his or her own work (Crocker et al. 1984).

As the conclusion, the success of the quality circles depends solely on the commitment of the top management and how they play their role to ensure the success of implementation of the quality circle in the organization. Below level staffs are valued and become an asset.Their sense of belonging to organization is further enhanced whenever their effort through the quality circles is well complimented by the top management. Like this company, the best group is given the opportunity to visit the parent company in Japan and Tokyo Disneyland. Hence, by introducing this concept of quality control in any organization, employees at the grassroots level have the opportunity to perform effectively and make a tremendous change in the working environment between management and the workforce.

The case study methodology used in this study has several limitations. The case study analysis was conducted based on one company only. However, the authors believed, it is adequate to show the QCC practices in achieving important goals that drive companies to reduce operating and manufacturing costs. This study is a part of an on-going research on QCC implementation in Malaysian manufacturing companies. Therefore, the results of this study must be treated with caution.

South-Western, Ohio 45040.

Foster, S. T. 2001. Managing Quality: An Integrative Approach, pp. 85, Prentice Hall, Upper Saddle River, New Jersey 07458.

Hitachi Malaysia. 1985. Company Report. Hitachi Malaysia. 1992. Company Report.

JUSE (Japanese Union of Scientist \& Engineers). 1994. Bagaimana Mengendalikan Kumpulan QCC (Terjemahan), NPC dan IS \& A, Kuala Lumpur.

Madura, J. 2004. Introduction to Business, 3rd Edition, Thomson, South-Western, Ohio 45040.

MNQC. 2002. Malaysian National QCC Convention (2002) - Handout.

Summers, D. C. S. 2005. Quality. 4th Edition, Prentice Hall, International Edition.

Talib, F. \& Ali, M. 2003. Impact of Quality Circle - a Case Study, IE(I) Journal, 1(84):10. 